\title{
Empowering midwives to manage postpartum haemorrhage in rural areas of Islamic Republic of Iran: lessons learnt from cases of maternal death
}

Zahra Moudi, ${ }^{1}$ Seyed Mehdi Tabatabaei, ${ }^{2}$ Zahra Sargazi-Moakhar, ${ }^{3}$ Sedighe Mollashahi, ${ }^{3}$ Maryam Zaboli ${ }^{3}$ and Shahram Borjian Boroojeny ${ }^{4}$

'Pregnancy Health Research Centre, Department of Midwifery, School of Nursing \&Midwifery, Zahedan University of Medical Sciences, Zahedan, Islamic Republic of Iran (Corresponding author Zahra Moudi: moudi@zaums.ac.ir). ${ }^{2}$ Pregnancy Health Research Centre, Department of Statistic and Epidemiology, Zahedan University of Medical Sciences, Zahedan, Islamic Republic of Iran. ${ }^{3}$ Department of Maternal and Child Health, Sistan and Baluchestan Province Health Centre, Zahedan, Islamic Republic of Iran. ${ }^{4}$ Pregnancy Health Research Centre, Department of Anaesthesiology, Sistan and Baluchestan Province Health Centre, Zahedan, Islamic Republic of Iran.

\begin{abstract}
Background: Postpartum haemorrhage is the main cause of maternal mortality in rural areas of low-income countries.

Aims: This study investigated the causes of maternal death from postpartum haemorrhage in rural areas of Sistan and Baluchestan, Islamic Republic of Iran, and determined the effect of three interventions on midwives' management of haemorrhage.
\end{abstract}

Methods: Maternal deaths in women with postpartum haemorrhage between 9 April 2012 and 9 April 2013 were reviewed to determine what contributed to the death. Following the review, prostaglandin was permitted for use in rural maternity units. A flowchart on managing haemorrhagic shock and a training workshop on management of postpartum haemorrhage were also developed for midwives working in rural areas. After the interventions, all cases of postpartum haemorrhage $(n=81)$ that occurred during 23 September 2014-23 February 2015 in rural maternity facilities were reviewed based on 19 indicators. A control group $(n=81)$ was selected from women with postpartum haemorrhage who had been admitted to the same maternity units before the interventions.

Results: After the training interventions, more midwives used more than one method to estimate blood loss and higher doses of oxytocin to control haemorrhage. They showed improvements in the use of intravenous fluid therapy, pulse and blood pressure checks, external uterine massage, and uterotonic drugs. Following training, more women were admitted to hospital in a stable condition and recovered and were discharged $(P=0.002)$, and fewer had surgical interventions $(P=0.007)$.

Conclusion: Midwives' management of postpartum haemorrhage improved after the interventions. Training programmes should be based on study of the local situation to identify shortcomings. Regular monitoring of outcomes is needed to detect and resolve failures.

Keywords: postpartum haemorrhage, maternal death, midwifery, training, Islamic Republic of Iran

Citation: Moudi Z; Tabatabaei S; Sargazi-Moakhar Z; Mollashahi S; Zaboli M; Boroojeny SB. Empowering midwives to manage postpartum haemorrhage in rural areas of Islamic Republic of Iran: lessons learnt from cases of maternal death. East Mediterr Health J. 2019;25(9):637-646. https://doi. org/10.26719/emhj.19.008

Received: 12/03/18; accepted: 09/08/18

Copyright @ World Health Organization (WHO) 2019. Some rights reserved. This work is available under the CC BY-NC-SA 3.0 IGO license https:// creativecommons.org/licenses/by-nc-sa/3.0/igo

\section{Introduction}

In 2015, around 303000 women worldwide died of pregnancy- and childbirth-related complications; $99 \%$ of these deaths occurred in low-income settings (1), mostly in the remote and rural areas (2).

Severe antepartum, intrapartum and postpartum bleeding is still the leading cause of maternal death $(1,3)$. This complication can kill a healthy woman within 2 hours (4). It is estimated that more than $25 \%$ of all maternal deaths and almost half of postpartum deaths are related to postpartum haemorrhage (5). The rate of postpartum haemorrhage has been reported to have increased in some high-income countries mainly because of atonic postpartum haemorrhage (6).

Primary postpartum haemorrhage is defined as vaginal bleeding of more than $500 \mathrm{ml}$ after childbirth
(7). More than $75 \%$ of deaths attributed to postpartum haemorrhage could be prevented. In low- and middleincome countries, postpartum haemorrhage mortality is high $(5,8)$. Previous studies have shown that treatment is most effective if started promptly (9). In $80 \%$ of cases of postpartum haemorrhage, women receive substandard care (10), underestimation of blood loss, delayed diagnosis and management of haemorrhage treatment failures (11), lack of easy-to-use local protocols (active management of the third stage of labour), lack of adequate education and training, and poor communication. In addition, organizational deficiencies, such as staff shortages, insufficient team work and coordination, and long distance between health care facilities and hospitals play an important role in the occurrence of adverse maternal complications and death in low- and middle-income countries $(3,6,12)$. 
Sistan and Baluchestan Province is the largest province in the Islamic Republic of Iran, with a population of 2.5 million. Villages are scattered over large areas and the province is affected by floods during periods of heavy rain. These problems make it difficult for nomadic people and villagers to easily access health services.

Zahedan and Iranshahr universities of medical science are in charge of health services in the province. The population covered by Zahedan University of Medical Sciences is 1620518 people. The university provides free health services through a broad network; this network has a referral system comprising health centres in the periphery going through to secondary and tertiary hospitals in the nearest urban areas and Zahedan, the provincial capital (13).

In rural areas, each village has a rural health centre, which has a doctor and 10 health workers who provide care and manage complex health problems. Some rural health centres have a maternity facility with trained midwives (14). These facilities provide delivery and maternal health care services for people living in the catchment areas of the health centre, including the main village where the health centres are located and satellite villages that are covered by the health centres. The health centre is the first contact between families and the health system in the Islamic Republic of Iran. It is staffed by a trained health care provider called a "behvarz". Behvarz are multipurpose health care workers who provide primary health care services to people living in rural areas $(13,15)$. According to the World Health Organization (WHO), Sistan and Baluchestan Province has shortages of health care providers (e.g. doctors and midwives [16]), and high employee turnover forces health care mangers to recruit staff from among inexperienced graduates.

The province has the highest total fertility rate (3.7 children per woman) in the country. Moreover, according to unpublished data (Vice-Chancellery for Health, Zahedan University of Medical Sciences, 2016), while the population covered by Zahedan University of Medical Sciences was about $2 \%$ of the total population of the Islamic Republic of Iran, $10.8 \%$ of maternal deaths in the country occurred in Sistan and Baluchestan. Previous studies have shown that postpartum haemorrhage was the leading cause of maternal morbidity and mortality in underprivileged provinces such as Sistan and Baluchestan (17).

Following such reports of maternal death associated with postpartum haemorrhage in rural delivery facilities in Sistan and Baluchestan, interventions were designed on the directive of the Deputy of Health of Zahedan University of Medical Sciences to improve the management of postpartum haemorrhage in the province.

The aim of our study was to investigate the effect of implementing a set of measures interventions (use of misoprostol, flowchart and a training workshop) on the performance of midwives in managing postpartum haemorrhage in rural areas of Sistan and Baluchestan Province.

\section{Methods}

A quasi-experimental (before and after) design was used to demonstrate the performance of midwives in managing postpartum haemorrhage before and after implementing the interventions. Women in the sample investigated before the intervention were different from those after the training intervention (18). The intervention phase of the study was designed in three stages.

\section{Investigating the reasons for maternal death from postpartum haemorrhage}

First, the medical records of all cases of postpartum haemorrhage that occurred in the areas covered by Zahedan University of Medical Sciences between 9 April 2012 and 9 April 2013 were reviewed by a panel of experts (including maternal health experts, midwives, physicians, and a reproductive health researcher) to investigate the cause of maternal death from postpartum haemorrhage.

The main problems in managing postpartum haemorrhage identified by the panel were: 1) management of the third stage of labour (e.g. lack of proper and timely use of oxytocic drugs); 2) delayed diagnosis of postpartum haemorrhage and underestimation of blood loss; 3) mismanagement of postpartum haemorrhage; 4) delay in deciding to refer the woman with postpartum haemorrhage to hospital; 5) inappropriate prescription of medications by general practitioners or midwives (including vitamin $\mathrm{K}$ or atropine and adrenaline for the management of bleeding or resuscitation); 6) insufficient administration of uterotonic drugs (e.g. oxytocin); 7) lack of familiarity with the signs and symptoms of shock; 8) inappropriate management of shock (e.g. insufficient fluid replacement); and 9) long distance between rural maternity units and the nearest hospital (average: $81.5 \mathrm{~km}$, range: $35-200 \mathrm{~km}$ ).

\section{Designing a set of measures}

Three measures were taken: 1) obtaining permission from the Ministry of Health and Medical Education to purchase and use prostaglandin (misoprostol) in rural areas; 2) developing a flowchart for the diagnosis and treatment of haemorrhagic shock in rural areas; and 3) training midwives working in rural areas.

\section{Permission to use prostaglandin (misoprostol)}

Because of the long distance between the maternity units and the nearest hospitals, administration of long-acting uterotonic drugs (misoprostol) would help manage postpartum haemorrhage. Therefore, permission for the use of this medicine, and the related guidelines on it, was obtained from the Iranian Ministry of Health and Medical Education. As a result, rural maternity facilities were supplied for the first time with pulse oximetry and misoprostol for the management of postpartum haemorrhage cases.

\section{Development of the training programme}

A training programme was developed based on the problems and malpractices that were identified on a 
review of cases of maternal death. In addition, a flowchart was developed using WHO guidelines, and guidelines on the diagnosis and treatment of postpartum haemorrhage and haemorrhagic shock were also devised (19-23). The draft obstetric haemorrhage flowchart was sent to a panel of experts including obstetricians, anaesthetists, physicians, midwives and public health authorities, and modifications were made based on their feedback and comments. The final draft of the flowchart was approved by the Department of Family Health, Population and School Health, and the Iranian Ministry of Health and Medical Education. The flowchart was designed for use as a wall chart to provide practical guidance for midwives on the diagnosis and management of haemorrhagic shock.

\section{Training general practitioners and midwives}

A team of experts (including maternal health experts, an obstetrician, an anaesthetist and a reproductive health researcher with a midwifery background) were the workshop facilitators and instructors. All midwives working in rural maternity facilities $(n=46)$ participated in a twoday training on how to manage the third stage of labour, and diagnosis and management of postpartum haemorrhage and shock using the WHO guidelines. The workshops were held in January and February 2014.

A total of 20-25 midwives and nine general practitioners participated in each training workshop. Midwives were divided into four groups and in each group, two to three general practitioners who worked in rural health centres were also included. Before starting the first day of the training workshop, each group was asked to write the step-by-step procedure for managing the third and fourth stages of labour. They were also encouraged and given some time during the workshop to share their real-life experiences. At the end of the first day of the workshop, the participants were asked to identify the differences between their actual practice at work and the instructions they were given in the workshop that were based on the standard protocols. They were encouraged to critically reflect on and challenge their own practices at work.

On the second day of training (management of postpartum haemorrhage and shock at maternity facilities and during referral to hospital), a summary of cases of four maternal deaths was given to the participants and they were asked to identify the key factors that led to the woman's death based on a three-delay model (delay in seeking care, delay in getting to a health facility, and delay in provision of adequate care) (24). At the end of each session, the participants' questions were answered and they were given training files.

\section{Evaluating changes after the training intervention}

Of 28 rural maternity facilities, those with more than 10 childbirths per month were selected $(n=20)$.

Six months after the training intervention, detailed information on the management of postpartum haemorrhage was collected from the records of all 81 cases of postpartum haemorrhage that occurred between 23 September 2014 and 23 February 2015 in rural maternity facilities. For each case of postpartum haemorrhage, the case of a woman who had had postpartum haemorrhage and had been admitted to the same maternity unit before the training intervention was selected as a control.

Data were collected through review of medical records by maternal health experts, who were trained to complete the case report form. Cases with postpartum haemorrhage were identified by the midwife in charge of the labour ward.

\section{Data collection instrument}

Data were collected using a 19-item case report form. A set of performance indicators for different aspects of management of postpartum haemorrhage in primary care settings was developed by the researchers. It included methods used to estimate blood loss; administering uterotonic medicines and intravenous fluid replacement therapy before hospital referral; timely hospital referral; administering uterotonic medicines and non-pharmaceutical measures such as uterine massage during referral; and women's condition at admission and outcome. After the draft case report form was developed, it was sent to five experts on the management of postpartum haemorrhage and training steps. They were asked to provide their comments (e.g. deletion of irrelevant items and addition of missing items) to ensure that the form included all relevant items. Then, the case report form was pilot-tested by 10 midwives in the field after which the final form was sent again to the above-mentioned panel of experts for their final approval.

The different aspects of postpartum haemorrhage management (before and during hospital referral) were compared between the pre-intervention and post-intervention groups. The data collected in the approved case report form included the following: cause of haemorrhage; diagnosis method; treating doctor informed when haemorrhage was diagnosed; length of time for doctor to reach the woman's bedside; uterotonic drugs given (type and amount); intravenous fluids given after diagnosis and up to hospital referral (type and amount); use of a pulse oximetry device; number of peripheral veins used for cannulation; intravenous catheter sizes and colours used for first and second intravenous lines; veins used for peripheral intravenous cannulation; Foley catheter inserted; length of time between haemorrhage diagnosis and calling for an ambulance; length of time between calling for an ambulance and arrival at hospital; measurement of vital signs and prevention of haemorrhage during patient transfer to the hospital; amount and type of intravenous fluids administered between haemorrhage diagnosis and arrival at hospital; patient's general condition at hospital admission; and care and outcome after hospital admission. 


\section{Statistical analysis}

SPSS, version 20, was used for statistical analyses. To compare categorical and binary data before and after the training intervention, data were analysed using the chisquared test and Fisher exact test for $2 \times 3,2 \times 4$ and $2 \times 5$ tables with cells with expected values less than 5 . Twotailed tests were used. A P-value less than 0.05 was considered statistically significant.

\section{Ethical considerations}

Our study aimed assess the effect of the use of WHO guidelines and common clinical management procedures for postpartum haemorrhage in Sistan and Baluchestan province. In the management of postpartum haemorrhage, nothing was done to the women beyond what the WHO guidelines and clinical management procedures recommended. In addition, we ensured that the results of the analysis did not identify subjects in order to preserve confidentiality and anonymity. Therefore, according to previous studies, for studies on quality control or medical audits, ethical review was not necessary, and use of personal medical records without involving the patients concerned is acceptable (25).

\section{Results}

Forty-seven midwives participated in the study, 53\% of whom had an associate degree (awarded by universities following a two-year degree programme) and the remainder had a bachelor degree; most (53\%) had graduated from government universities and $46.8 \%$ from Azad University (private university). The majority of the midwives $(79 \%)$ had more than four years of work experience, $17 \%$ had $2-4$ years and $4 \%$ had less than two years of work experience.

In terms of the performance of the midwives before and after the training intervention, a significantly greater proportion of the midwives in the post-intervention group used more than one method to estimate the extent of haemorrhage other than observation (such as the weight and the number of blood-soaked sheets, changes in blood pressure and pulse, deteriorating general condition, and primary signs of shock) (Table 1).

The trainings resulted in a higher doses of oxytocin being given to control haemorrhage and also misoprostol being given (Table 2). Misoprostol was mainly used in rural areas (14 cases) where the driving time to the nearest hospital was about two hours. After implementing the haemorrhage management training intervention, significant improvements were seen in IV fluid therapy measures taken before referral of pregnant women to hospital (Table 3).

After the training intervention, the midwives' management of haemorrhage during the referral of pregnant women on their way to hospital in the ambulance significantly improved in terms of the number of peripheral IV lines inserted, the volume of IV fluid given, regular pulse and blood pressure checks, external uterine massage, and administration of uterotonic drugs (Table 4). After the training, a significantly greater proportion of women with haemorrhaging were admitted to hospitals in a stable condition.

In comparison with women in the pre-intervention group, those in the post-intervention group were significantly more likely to recover and be discharged $(56 \%$ versus $44 \%)(P=0.002)$ and less likely to have surgical interventions ( $17 \%$ versus $83 \%)(P=0.0007)$ (Table 4$)$. Fewer were also admitted to the intensive care unit (44\% versus $56 \%$ ) but the difference was not statically significant. One woman died in the post-intervention group while there were no cases of maternal mortality in the preintervention group.

\section{Discussion}

Our study showed that following the interventions - use of misoprostol, flowchart and training - midwives' management of postpartum haemorrhage improved significantly in most areas.

In line with our results, Esscher (2014) noted that analysis of the etiology of death could clarify why the incidence of maternal death was higher in some groups (26). WHO reported that many countries have made progress in managing births in health facilities, but this

\begin{tabular}{|c|c|c|c|c|c|}
\hline \multirow{2}{*}{ Variable } & \multicolumn{2}{|c|}{ Before } & \multicolumn{2}{|c|}{ After } & \multirow{2}{*}{ P-value ${ }^{b}$} \\
\hline & No. & $\%$ & No. & $\%$ & \\
\hline \multicolumn{6}{|l|}{ Bleeding cause } \\
\hline Uterine atony & 45 & 58 & 33 & 42 & \multirow{3}{*}{0.163} \\
\hline Tear(s) to the vagina & 11 & 41 & 16 & 59 & \\
\hline Retained placenta & 25 & 44 & 32 & 56 & \\
\hline \multicolumn{6}{|l|}{ Bleeding diagnosis method } \\
\hline More than one method ${ }^{a}$ & 14 & 19 & 60 & 81 & \multirow{2}{*}{0.001} \\
\hline Observation only & 67 & 76 & 21 & 24 & \\
\hline
\end{tabular}

${ }^{a}$ Weight and the number of blood-soaked sheets, changes in blood pressure and pulse, deteriorating general condition and primary signs of shock.

${ }^{b}$ Chi-squared test. 
Table 2 Haemorrhage management measures before referral of pregnant women to hospital, before and after implementing haemorrhage management training sessions

\begin{tabular}{|c|c|c|c|c|c|}
\hline \multirow{2}{*}{ Variable } & \multicolumn{2}{|c|}{ Before $(n=81)$} & \multicolumn{2}{|c|}{ After $(\mathbf{n}=\mathbf{8 1})$} & \multirow{2}{*}{ P-value ${ }^{\mathrm{b}}$} \\
\hline & No. & $\%$ & No. & $\%$ & \\
\hline \multicolumn{6}{|l|}{ Physician attendance time (min) } \\
\hline$\leq 5$ & 46 & 44 & 59 & 56 & \multirow{2}{*}{$0.032^{\mathrm{a}}$} \\
\hline$>5$ & 35 & 61 & 22 & 39 & \\
\hline \multicolumn{6}{|c|}{ Time from diagnosis to calling ambulance (min) } \\
\hline$\leq 10$ & 45 & 45 & 56 & 55 & \multirow{2}{*}{$0.074^{\mathrm{a}}$} \\
\hline$>10$ & 36 & 59 & 25 & 41 & \\
\hline \multicolumn{6}{|l|}{ Ambulance arrival time (min) } \\
\hline$\leq 10$ & 68 & 48 & 75 & 52 & \multirow{2}{*}{$0.087^{\mathrm{a}}$} \\
\hline$>10$ & 13 & 68 & 6 & 32 & \\
\hline \multicolumn{6}{|c|}{ Time from diagnosis to hospital admission (min) } \\
\hline$\leq 60$ & 3 & 12 & 21 & 88 & \multirow{2}{*}{$0.001^{b}$} \\
\hline$>60$ & 78 & 56 & 60 & 44 & \\
\hline \multicolumn{6}{|l|}{ Oxytocin administered (IU) } \\
\hline$\leq 10$ & 71 & 84 & 14 & 16 & \multirow{3}{*}{$0.001^{b}$} \\
\hline $11-20$ & 10 & 59 & 7 & 41 & \\
\hline$>20$ & 0 & 0 & 60 & 100 & \\
\hline \multicolumn{6}{|l|}{ Methergine administered } \\
\hline No & 60 & 54 & 52 & 46 & \multirow{2}{*}{$0.174^{a}$} \\
\hline Yes & 21 & 42 & 29 & 58 & \\
\hline \multicolumn{6}{|l|}{ Misoprostol administered } \\
\hline No & 81 & 55 & 67 & 45 & \multirow{2}{*}{$0.001^{b}$} \\
\hline Yes & 0 & 0 & 14 & 100 & \\
\hline
\end{tabular}

${ }^{a}$ Chi-squared test.

${ }^{b}$ Fisher exact test.

Table 3 Intravenous (IV) fluid therapy measures taken by midwives before referral of pregnant women to hospital, before and after implementing haemorrhage management training sessions

\begin{tabular}{|c|c|c|c|c|c|}
\hline \multirow{2}{*}{ Variable } & \multicolumn{2}{|c|}{ Before } & \multicolumn{2}{|c|}{ After } & \multirow{2}{*}{ P-value } \\
\hline & No. & $\%$ & No. & $\%$ & \\
\hline \multicolumn{6}{|l|}{ Number of IV lines secured } \\
\hline 1 & 75 & 94 & 5 & 6 & \multirow{2}{*}{$0.001^{a}$} \\
\hline 2 or more & 6 & 7 & 76 & 93 & \\
\hline \multicolumn{6}{|l|}{ First IV line catheter size } \\
\hline Blue $(22 \mathrm{G})$ & 2 & 100 & 0 & 0 & \multirow{3}{*}{$0.001^{\mathrm{a}}$} \\
\hline Pink (20G) & 69 & 57 & 52 & 43 & \\
\hline Green (18G) & 10 & 26 & 29 & 74 & \\
\hline \multicolumn{6}{|l|}{ Second IV line catheter size } \\
\hline None & 75 & 94 & 5 & 6 & \multirow{3}{*}{$0.001^{\mathrm{a}}$} \\
\hline Green (18G) & 6 & 8 & 73 & 92 & \\
\hline Grey (16G) & 0 & 0 & 3 & 100 & \\
\hline \multicolumn{6}{|l|}{ Type of IV fluid administered } \\
\hline Normal saline & 18 & 69 & 8 & 31 & \multirow{4}{*}{$0.001^{\mathrm{a}}$} \\
\hline Ringer/ringer lactate & 47 & 57 & 36 & 43 & \\
\hline Ringer + normal saline & 0 & 0 & 37 & 100 & \\
\hline Other & 16 & 100 & 0 & 0 & \\
\hline
\end{tabular}


Table 3 Intravenous (IV) fluid therapy measures taken by midwives before referral of pregnant women to hospital, before and after implementing haemorrhage management training sessions (concluded)

\begin{tabular}{|c|c|c|c|c|c|}
\hline \multirow{2}{*}{ Variable } & \multicolumn{2}{|c|}{ Before } & \multicolumn{2}{|c|}{ After } & \multirow{2}{*}{$P$-value } \\
\hline & No. & $\%$ & No. & $\%$ & \\
\hline \multicolumn{6}{|l|}{ IV line insertion site } \\
\hline Back of hand & 38 & 97 & 1 & 3 & \multirow{5}{*}{$0.001^{a}$} \\
\hline Wrist & 31 & 67 & 15 & 33 & \\
\hline Forearm & 2 & 29 & 5 & 71 & \\
\hline Elbow & 2 & 33 & 4 & 67 & \\
\hline Two sites & 8 & 12 & 56 & 88 & \\
\hline \multicolumn{6}{|l|}{ IV fluid volume (L) } \\
\hline 0.5 & 45 & 56 & 36 & 44 & \multirow{4}{*}{$0.304^{b}$} \\
\hline 1.0 & 12 & 52 & 11 & 48 & \\
\hline 1.5 & 15 & 47 & 17 & 53 & \\
\hline 2.0 & 9 & 35 & 17 & 65 & \\
\hline \multicolumn{6}{|l|}{ Pulse oximetry } \\
\hline Yes & 0 & 0 & 66 & 100 & \multirow{2}{*}{$0.001^{a}$} \\
\hline No & 81 & 84 & 15 & 16 & \\
\hline \multicolumn{6}{|l|}{ Foley catheter inserted } \\
\hline Yes & 8 & 11 & 67 & 89 & \multirow{2}{*}{$0.001^{b}$} \\
\hline No & 73 & 94 & 14 & 16 & \\
\hline
\end{tabular}

a Fisher exact test.

${ }^{b}$ Chi-squared test.

Table 4: Haemorrhage management measures during referral of pregnant women to hospital, and women's condition on admission and management, before and after implementing haemorrhage management training sessions

\begin{tabular}{|c|c|c|c|c|c|}
\hline \multirow{2}{*}{ Variable } & \multicolumn{2}{|c|}{ Before } & \multicolumn{2}{|c|}{ After } & \multirow{2}{*}{ P-value } \\
\hline & No. & $\%$ & No. & $\%$ & \\
\hline \multicolumn{6}{|l|}{ No. of IV lines secured } \\
\hline 1 & 74 & 94 & 5 & 6 & \multirow{2}{*}{$0.001^{d}$} \\
\hline 2 & 7 & 8 & 76 & 92 & \\
\hline \multicolumn{6}{|l|}{ IV fluid administered (L) } \\
\hline 0 & 3 & 23 & 10 & 77 & \multirow{5}{*}{$0.0003^{\mathrm{e}}$} \\
\hline 0.5 & 35 & 57 & 26 & 43 & \\
\hline 1 & 14 & 88 & 2 & 12 & \\
\hline 1.5 & 6 & 67 & 3 & 33 & \\
\hline$\geq 2$ & 23 & 36 & 40 & 64 & \\
\hline \multicolumn{6}{|c|}{ Blood pressure monitored every 15 mins } \\
\hline Yes & 49 & 38 & 81 & 62 & \multirow{2}{*}{$0.0001^{\mathrm{e}}$} \\
\hline No & 32 & 100 & 0 & 0 & \\
\hline \multicolumn{6}{|l|}{ Pulse monitored every 15 mins } \\
\hline Yes & 1 & 1 & 71 & 99 & \multirow{2}{*}{$0.001^{e}$} \\
\hline No & 80 & 89 & 10 & 11 & \\
\hline \multicolumn{6}{|l|}{ Uterine massage } \\
\hline Yes & 0 & 0 & 24 & 100 & \multirow{2}{*}{$0.0001^{\mathrm{e}}$} \\
\hline No & 81 & 59 & 57 & 41 & \\
\hline \multicolumn{6}{|l|}{ Oxytocin administered (IU) } \\
\hline$\leq 10$ & 81 & 51 & 77 & 49 & \multirow{2}{*}{$0.12^{\mathrm{e}}$} \\
\hline $11-40$ & 0 & 0 & 4 & 100 & \\
\hline
\end{tabular}


Table 4 Haemorrhage management measures during referral of pregnant women to hospital, and women's condition on admission and management, before and after implementing haemorrhage management training sessions (concluded)

\begin{tabular}{|c|c|c|c|c|c|}
\hline \multirow{2}{*}{ Variable } & \multicolumn{2}{|c|}{ Before } & \multicolumn{2}{|c|}{ After } & \multirow{2}{*}{ P-value } \\
\hline & No. & $\%$ & No. & $\%$ & \\
\hline \multicolumn{6}{|l|}{ Methergene administered } \\
\hline Yes & 0 & 0 & 18 & 100 & \multirow{2}{*}{$0.0001^{e}$} \\
\hline No & 81 & 56 & 63 & 44 & \\
\hline \multicolumn{6}{|l|}{ Misoprostol administered } \\
\hline Yes & 0 & 0 & 17 & 0 & \multirow{2}{*}{$0.0001^{e}$} \\
\hline No & 81 & 56 & 64 & 44 & \\
\hline \multicolumn{6}{|l|}{ Condition at hospital admission } \\
\hline Stablea & 36 & 35 & 67 & 65 & \multirow{3}{*}{$0.0001^{e}$} \\
\hline Decreased level of consciousness & 42 & 76 & 13 & 24 & \\
\hline Comatose & 3 & 75 & 1 & 25 & \\
\hline \multicolumn{6}{|l|}{ Outcome $^{b}$} \\
\hline Recovered and discharged & 56 & 44 & 72 & 56 & $0.0004^{d}$ \\
\hline ICU admission & 5 & 56 & 4 & 44 & $0.7^{e}$ \\
\hline Surgical interventions & 19 & 83 & 4 & 17 & $0.0007^{e}$ \\
\hline Referred to tertiary care hospital & 1 & 100 & 0 & 0 & - \\
\hline Died $^{c}$ & 0 & 0 & 1 & 100 & - \\
\hline
\end{tabular}

IV: intravenous; ICU: intensive care unit.

${ }^{a}$ Pulse $<100$, systolic blood pressure $>80 \mathrm{mmHg}$.

${ }^{b}$ All mothers admitted to the ICU and who had surgical interventions recovered and were later discharged from the hospital.

'After giving birth outside the hospital and postpartum haemorrhage occurring, it took 1 hour to transfer the woman to hospital. She died after admission to hospital in shock. ${ }^{\mathrm{d} C h i-s q u a r e d ~ t e s t . ~}$

${ }^{e}$ Fisher exact test.

often does not lead to a reduction in maternal mortality. This is due to the quality of care provided in health facilities (27). In fact, to ensure quality of care for maternal health requires evidence-based and systematic approaches to identify effective strategies and interventions and develop monitoring indicators at the facility level (28). In addition, it is important to find strategies and interventions that take account of the regional context and resources and that can be implemented within the existing health care systems (29).

Provision of good quality care in health care facilities, especially in remote areas, can be achieved through competent midwives and health care providers $(27,29,30)$. In line with our study, Evans (2014) showed that oneday simulation training in postpartum haemorrhage prevention and management could boost the knowledge and confidence of midwives (31). In addition, our study showed that training on the prevention (active management of third stage of labour) (20), detection (blood loss) and management of postpartum haemorrhage (on-site and during referral), and the use of simple measures, such as emptying the bladder, uterine massage, intramuscular and intravenous administration of injectable uterotonic drugs (e.g. oxytocin) and misoprostol can improve maternal outcomes and be lifesaving in remote areas $(12,32)$.

One woman died in the post-intervention group (she was in shock on admission to hospital), while there were no cases of maternal mortality in the preintervention group. Training together with regular audits, monitoring of local outcomes, and feedback can help ensure adherence to the regulations and standards of care, thereby reducing the prevalence of postpartum haemorrhage and maternal mortality $(6,33,34)$.

Our study had a number of limitations. First, the sample size was fairly small which could decrease statistical power. Second, we examined the simultaneous implementation of three interventions (use of prostaglandin, a flowchart and a training workshop). Therefore, it was not possible to separate the effect of each intervention on the improvement of the health outcomes following postpartum haemorrhage. Nevertheless, we believe that these limitations do not undermine the value of the study because the interventions clearly led to improvement in the management of postpartum haemorrhage by midwives in a low-resource district.

Based on the present findings, training midwives who provide childbirth services to mothers can improve the health outcomes of mothers following postpartum haemorrhage in rural areas. Training programmes should be based on the study of maternal death records and review of maternal medical records. Finally, regular monitoring of outcomes is needed after the interventions to detect and promptly resolve any failures that may occur. 


\section{Acknowledgments}

We thank the midwives who participated in the training course, the staff for contributing to data collection, and Zahedan University of Medical Sciences for logistics support.

Funding: None.

Competing interests: None declared.

\section{Permettre aux sages-femmes de prendre en charge les hémorragies du postpartum dans les zones rurales de la République islamique d'Iran : enseignements tirés de cas de décès maternels}

\section{Résumé}

Contexte : Les hémorragies du postpartum constituent la principale cause de mortalité maternelle dans les zones rurales des pays à revenu faible.

Objectifs : La présente étude a examiné les causes de mortalité maternelle par hémorragie du postpartum dans les zones rurales du Sistan et du Baloutchistan (République islamique d'Iran) et a déterminé l'impact de trois interventions sur la prise en charge des hémorragies par les sages-femmes.

Méthodes : Les décès maternels de femmes par hémorragie du postpartum enregistrés entre le 9 avril 2012 et le 9 avril 2013 ont été examinés afin de déterminer les facteurs ayant entraîné le décès. Suite à cet examen, l'utilisation de la prostaglandine a été autorisée dans les maternités en milieu rural. Un tableau sur la gestion des chocs hémorragiques a été réalisé. Un atelier de formation consacré à la prise en charge des hémorragies du postpartum a également été mis en place à l'attention des sages-femmes travaillant en zones rurales. À l'issue des interventions, tous les cas d'hémorragie du postpartum ( $n=81$ ) survenus entre le 23 septembre 2014 et le 23 février 2015 dans les maternités des régions rurales ont été passés en revue sur la base de 19 indicateurs. Un groupe témoin $(n=81)$ a été sélectionné parmi les femmes atteintes d'hémorragie du postpartum qui avaient été admises dans les mêmes services de maternité avant les interventions.

Résultats : Après les interventions de formation, un plus grand nombre de sages-femmes ont eu recours à plusieurs méthodes pour évaluer les pertes de sang et administrer des doses plus élevées d'ocytocine afin de maîtriser les hémorragies. Elles ont fait preuve d'améliorations en matière de l'utilisation de la thérapie par liquide intraveineux, la vérification du pouls et de la pression artérielle, du massage externe de l'utérus et de médicaments utérotoniques. Suite à la formation, un plus grand nombre de femmes ont été hospitalisés dans un état stable avant de récupérer et de sortir de l'hôpital ( $p=0,002)$, et moins de femmes ont subi des interventions chirurgicales ( $p=0,007)$.

Conclusion : Nous avons observé une amélioration de la prise en charge des hémorragies du postpartum par les sagesfemmes après les interventions. Les programmes de formation doivent être basés sur l'étude de la situation locale afin d'identifier les lacunes. Un suivi régulier des résultats est nécessaire afin de détecter et de résoudre les défaillances.

$$
\begin{aligned}
& \text { تمكين القابلات للتصدي لنزف ما بعد الوضع في المناطق الريفية بجمهورية إيران الإسلامية: الدروس المستفادة من } \\
& \text { حالات وفيات الأمهات } \\
& \text { زهر امودي، سيد مهدي طبطبائي، زهرة مؤخر، صديقة ملاشاهي، مريم زعبولي، شهرام بوروجيني } \\
& \text { الخالاصة } \\
& \text { الخلفية: يُعدّ نزف ما بعد الو ضع السبب الرئيسي لوفيات الأمهات في المناطق الريفية بالبلدان ذات الدخل المنخفض. } \\
& \text { الأهداف: بحثت هذه الدراسة أسباب وفاة الأمهات من نزف ما بعد الوضع في المناطق الريفية في سيستان وبلوشستان، وحلَّدت تأثير ثلاثة }
\end{aligned}
$$

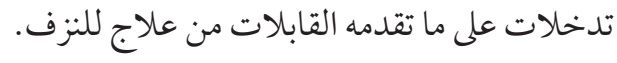

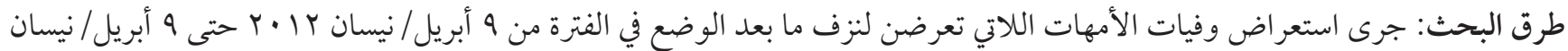

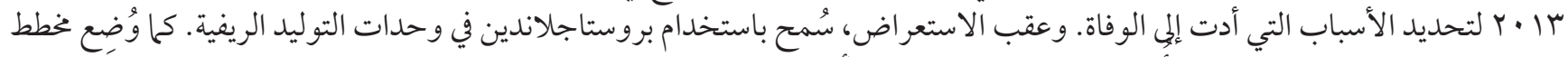

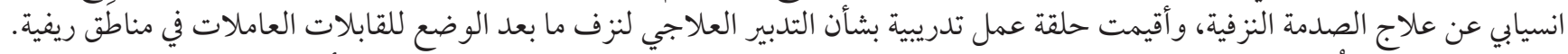

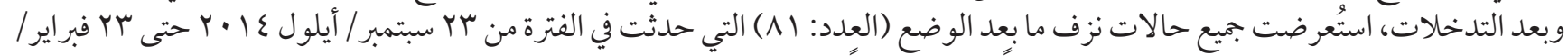

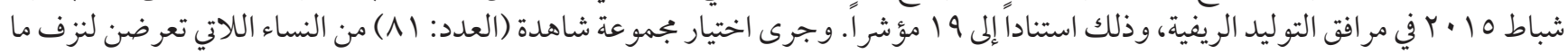

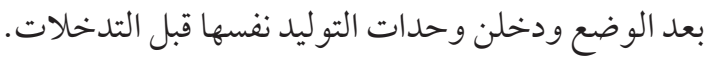

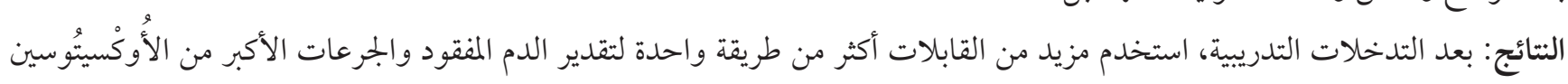




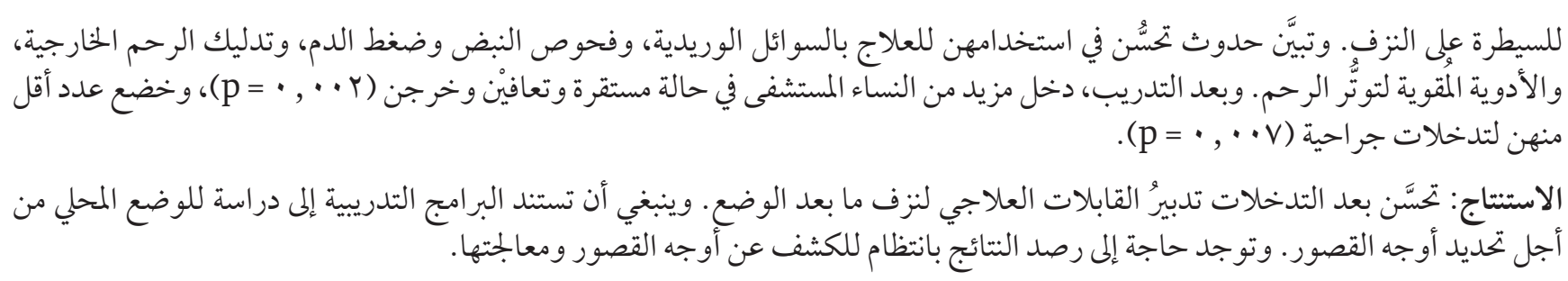

\section{References}

1. Maternal mortality. Fact sheet. World Health Organization; 16 February 2018 (http://www.who.int/mediacentre/factsheets/ fs348/en/, accessed 5 March 2019).

2. Vallely LM, Homiehombo P, Walep E, Moses M, Tom M, Kelly-Hanku A, et al. Feasibility and acceptability of clean birth kits containing misoprostol for self-administration to prevent postpartum hemorrhage in rural Papua. Int J Gynaecol Obstet. 2016;133:301-6.

3. Sanghvi H, Ansari N, Prata NJV, Gibson H, Ehsan A, Smith JM. Prevention of postpartum hemorrhage at home birth in Afghanistan. Int J Gynaecol Obstet. 2010;108:276-81.

4. Media centre. World blood donor day: safe blood needed to save mothers. World Health Organization; 10 June 2014 (www.who. int/mediacentre/news/releases/2014/world-blood-donor-day/en/, accessed 5 March 2019).

5. Venditteli F, Barasinski C, Pereira B, Dreyfus M, Lemery D, Bouvier-Colle MH. Policies for management of postpartum haemorrhage: the HERA cross-sectional study in France. Eur J Obstet Gynecol Reprod Biol. 2016;205:21-6.

6. Bohlmann MK, Rath W. Medical prevention and treatment of postpartum hemorrhage: a comparison of different guidelines. Arch Gynecol Obstet. 2014;289(3):555-67.

7. Pocket book of hospital care for mothers. World Health Organization; 2017 (https://apps.who.int/iris/handle/10665/258716, accessed 5 March 2019).

8. Making pregnancy safer. Reducing the global burden: postpartum haemorrhage. Geneva: World Health Organization; 2007 (www.who.int/maternal_child_adolescent/documents/newsletter/mps_newsletter_issue4.pdf, accessed 5 March 2019).

9. Kerr NL, Hauswald M, Tamrakar SR, Wachter DA, Baty GM. An inexpensive device to treat postpartum hemorrhage: a preliminary proof of concept study of health provider opinion and training in Nepal. BMC Pregnancy Childbirth. 2014;24:14:81.

10. Peate I, Hamilton C, editors. The students guide to becoming a midwife. 2nd edition. Chichester: John Wiley \& Sons Ltd; 2014.

11. Liu Y, Shen Y, Zhu W, Qiu JB, Huang Q, Ye WQ. Clinical assessment indicators of postpartum hemorrhage: a systematic review. Chinese Nursing Res. 2017;4:170-7.

12. Stanton CK, Newton S, Mullany LC, Cofie P, Agyemang CT, Adiibokah E, et al. Impact on postpartum hemorrhage of prophylactic administration of oxytocin 10 IU via Uniject TM by peripheral health care providers at home births: design of a community-based cluster-randomized trial. BMC Pregnancy Childbirth. 2012; 12:42.

13. Mehrdad R. Health system in Iran. Japan Med Assoc J. 2009;52(1):69-73.

14. Tabatabaei SM, Behmanesh Pour F, Share Mollashahi S, Sargazi Moakhar Z, Zaboli M. The Quality gap in the services provided by Rural Maternity Units in south-east of Iran. Health Scope. 2015;4(4):e25344.

15. Tabrizi JS, Pourasghar F, Gholamzadeh Nikjoo R. Status of Iran's primary health care system in terms of health system control knobs: a review article. Iran J Public Health. 2017;46(9):1156-66.

16. Health system profile. Islamic Republic of Iran. Cairo: World Health Organization Regional Office for the Eastern Mediterranean; 2006 (apps.who.int/medicinedocs/documents/s17294e/s17294e.pdf, accessed 5 March 2019).

17. Dadipoor S, Mehraban M, Ziapour A, Safari-Moradabadi A. Causes of maternal mortality in Iran: a systematic review. Int J Pediatr. 2017;5(12):6757-70.

18. Grimshaw J, Campbell M, Eccles M, Steen N. Experimental and quasi-experimental designs for evaluating guideline implementation strategies. Fam Pract. 2000;17(1):S11-6.

19. Krausz MM. Initial resuscitation of hemorrhagic shock. World J Emerg Surg. 2006;1:14.

20. Managing postpartum haemorrhage. Educational material for teachers of midwifery. Midwifery education modules. 2nd edition. Geneva: World Health Organization; 2008 (https://apps.who.int/iris/bitstream/handle/10665/44145/9789241546669_5_eng. pdf?sequence $=5$, accessed 5 March 2019).

21. Managing incomplete abortion. Educational material for teachers of midwifery. Midwifery education module 6.2nd edition. Geneva: World Health Organization; 2008 (https://apps.who.int/iris/bitstream/handle/10665/44145/9789241546669_3_eng. pdf?sequence=3, accessed 5 March 2019).

22. WHO guidelines for the management of postpartum haemorrhage and retained placenta. Geneva: World Health Organization; 2009 (https://apps.who.int/iris/bitstream/handle/10665/44171/9789241598514_eng.pdf?sequence=1, accessed 5 March 2019).

23. WHO recommendations for the prevention and treatment of postpartum haemorrhage. Geneva: World Health Organization; 2012 (apps.who.int/iris/bitstream/10665/75411/1/9789241548502_eng.pdf, accessed 5 March 2019). 
24. Thaddeus S, Maine D. Too far to walk: maternal mortality in context. Soc Sci Med. 1994;38(8):1091-110.

25. Access to medical records for the purpose of medical audit. BMJ. 1993; 3 April (https://www.bmj.com/content/bmj/306/6882/896.5.full.pdf, accessed 5 March 2019).

26. Esscher A, Binder-Finnema P, Bodker B, Hogberg U, Mulic-Lutvica A, Essen B. Suboptimal care and maternal mortality among foreign-born women in Sweden: maternal death audit with application of the "migration three delays" model. BMC Pregnancy Childbirth. 2014; 14:141.

27. Maternal, newborn, child and adolescent health. What is quality of care and why is it important? World Health Organization; 2017 (www.who.int/maternal_child_adolescent/topics/quality-of-care/definition/en/, accessed 5 March 2019).

28. Tuncalp, Were WM, MacLennan C, Oladapo OT, Gulmezoglu AM, Bahl R, et al. Quality of care for pregnant women and newborns-the WHO vision. BJOG. 2015;122(8):1045-9.

29. Geller SE, Adams MG, Kelly PJ, Kodkany BS, Derman RJ. Postpartum hemorrhage in resource-poor settings. Int J Gynaecol Obstet. 2006;92(3):202-11.

30. Fauveau V, Sherratt DR, de Bernis L. Human resources for maternal health: multi-purpose or specialists? Hum Resour Health. 2008;6:21.

31. Evans CL, Johnson P, Bazant E, Bhatnagar N, Zgambo J, Khamis A. Competency-based training "helping mothers survive: bleeding after birth" for providers from central remote facilities in three countries. Int J Gynaecol Obstet. 2014;126:286-90.

32. Black RE, Laxminarayan R, Temmerman M, Walker N. Disease control priorities. Reproductive, maternal, newborn, and child health. Washington, DC: World Bank Group; 2016 (https://www.ncbi.nlm.nih.gov/books/NBK361907/pdf/Bookshelf_NBK361907. pdf, accessed 5 March 2019).

33. Nair M, Yoshida S, Lambrechts T, Boschi-Pinto C, Bose K, Mason EM, et al. Facilitators and barriers to quality of care in maternal, newborn and child health: a global situational analysis through meta review. BMJ Open. 2014; 4(5):eoo4749.

34. Crofts J, Mukuli T, Murove BT, Ngwenya S, Mhlanga S, Dube M, et al. Onsite training of doctors, midwives and nurses in obstetric emergencies, Zimbabwe. BUll World Health Organ. 2015;93(5):347-51. 